\title{
Ilgalaikio antipsichotikų vartojimo sukeltos vẻlyvosios diskinezijos gydymas: klinikinių atvejų aprašymas ir literatūros apžvalga
}

\section{Pabarčiūtè*}

M. Karnickas**

*Vilniaus universiteto

Medicinos fakultetas

**Respublikine Vilniaus

psichiatrijos ligonine,

Universitetinis skyrius
Santrauka. Ivadas. Vèlyvoji diskinezija - judejjimo sutrikimas, prasidedantis bent keletą mėnesių vartojant dopamino receptorių blokatorius. Šie vaistai apima daugumą vaistų nuo psichozès, kurių vartojimas plačiai taikomas gydant psichikos ligas. Ši neigalumą sukelianti būklè išliks klinikine šiuolaikinès psichiatrijos dalimi, o pastaraisiais metais literatūroje pasirodęs didelis publikacijų apie vèlyvająa diskineziją skaičius yra didžiulis postūmis šioje srityje.

Atvejų aprašymai. 43 metų moteris, serganti paranoidine šizofrenija, $2018 \mathrm{~m}$. hospitalizuota dèl viso kūno nuolatinių nevalingų judesių, itin išreikštų apie 2 metus. Pacientė antipsichotikus vartoja apie 20 metų, pirmieji diskineziniai judesiai pastebėti prieš 10 metų (ịvairūs trūkčiojimai) ir aprašyti $2014 \mathrm{~m}$. (čepsẻjimas). Pacientei diagnozuota vèlyvoji diskinezija, paskirtas gydymas tetrabenazinu. Pacientès būklè stacionare akivaizdžiai gerèjo, stereotipiški distoniniai-hiperkineziniai galūnių ir liemens judesiai bei kiti simptomai išnyko.

Kita paciente - 55 metų moteris, 2019 m. hospitalizuota dèl nevalingų judesių, reguliariai antipsichotikus vartojusi apie 10 metų dèl kliedesinio sutrikimo. Akatizija ir rankų diskinezijos atsirado prieš 7 metus, pamažu progresavo iki veido, kaklo, rankų, liemens choreoatetoidinių judesių. Hospitalizacijos metu diagnozuota paranoidinè šizofrenija, vėlyvoji diskinezija, paskirtas gydymas tetrabenazinu. Gydant sumažèjo nevalingų judesių amplitudè, pacientè tapo labiau funkcionali.

Literatūros apžvalga. Vienas sunkumų psichiatrijoje, gydant vèlyvają diskineziją, - poreikis tęsti būklę sąlygojusius antipsichotikus. Geriausias pasirinkimas būtu antros kartos atipiniai antipsichotikai. Pirmo pasirinkimo vaistai vėlyvajai diskinezijai gydyti yra VMAT2 inhibitoriai - deutetrabenazinas, valbenazinas, jei šie vaistai neprieinami - tetrabenazinas.

Išvados. Norint pateikti patikimas, irodymais pagrịstas vẻlyvosios diskinezijos gydymo rekomendacijas, geriau suprasti jos patofiziologiją, genetinę predispoziciją ir gydymui skirtus preparatus, reikètų atlikti daugiau, didesnių imčių ir vienodesnių sąlygų tyrimų.

Raktažodžiai: vėlyvoji diskinezija, vėlyvosios diskinezijos gydymas.

\section{IVADAS}

Vèlyvoji diskinezija (VD) yra jatrogeninis, lètinis judejjimo sutrikimas, atsirandantis dèl ilgalaikio dopamino re-

\author{
Adresas: \\ Marius Karnickas \\ Respublikine Vilniaus psichiatrijos ligonine, \\ Universitetinis skyrius \\ Parko g. 21, LT-11205 Vilnius \\ El.paštas marius.karnickas@mf.vu.lt
}

ceptorių blokatorių (DRB) vartojimo [1]. Visi DRB, įskaitant tipinius ar pirmos kartos antipsichozinius vaistus, netipinius ar antros kartos antipsichotikus, trečios kartos antipsichotikus (aripiprazolas) ir vaistus, vartojamus virškinimo trakto sutrikimams gydyti (pvz., metoklopramidas), gali sukelti VD. Nors antros kartos antipsichotikai yra susiję su mažesne VD rizika, jų ịvedimas neturèjo didelio poveikio VD dažniui [2]. Iš dalies taip yra todèl, kad, išplètus skyrimo indikacijas, padidejjo jų vartojimas [3]. Daugelis DRB yra patvirtinti ne tik šizofrenijos, bet ir bipolinio afektinio sutrikimo, depresijos epizodų ar dirglumo autiz-

(C) Neurologijos seminarai, 2020. Open Access. This article is distributed under the terms of the Creative Commons Attribution 4.0 International License CC-BY 4.0 (http://creativecommons.org/licenses/by/4.0/), which permits unrestricted use, distribution, and reproduction in any medium, provided you give appropriate credit to the original author(s) and the source, provide a link to the Creative Commons license, and indicate if changes were made. 
mo spektro sutrikimams gydyti ir dažnai vartojami ne pagal informacinio lapelio reikalavimus (angl. off label) (dèl nerimo, nemigos ir kt.). VD išlieka sudètingu ir sunkiai valdomu sutrikimu. Taip yra dèl to, kad paprastai išlieka poreikis toliau vartoti VD sukèlusius antipsichotikus, varijuoja jos klinikinè išraiška ir vis dar trūksta patikimų prognozių, leidžiančių stratifikuoti riziką [2]. Apskaičiuota, kad VD pasireiškia apie $25 \%$ pacientų, gydomų bet kokiais antipsichotikais [4]. Vienas sunkumų, gydant VD, yra poreikis ir toliau tęsti antipsichotikų vartojimą, kurie ir sukèlè būklę [5].

Vidutinio sunkumo ar sunki VD gali sukelti neigalumą ir reikšmingai paveikti sergančiojo kasdienę veiklą, bloginti gyvenimo kokybę, kartais net sukelti grèsmę gyvybei [6]. $20 \%$ sergančiųjų VD patiria reikšmingų funkcijų apribojimu [7]. $2020 \mathrm{~m}$. atliktame tyrime paskelbta, kad iš 204 pacientų, sergančių VD, 75,5 \% teigè esantys susidrovejję ar susigèdę dẻl savo nevalingų judesių, kurių negalèjo suvaldyti. Tokie jausmai gali sustiprinti jau esamus psichiatrinius simptomus (pvz., prislègtą nuotaiką, nerimą) ir prisidèti prie stigmatizacijos bei socialinès izoliacijos [8]. Pastaraisiais metais îvyko nepaprastai didelis postūmis nuo nihilistinio požiūrio ị VD, kai literatūroje pasirodė daug publikacijų, kuriose aptariamos naujos ižvalgos apie VD patofiziologiją ir naujus vaistus [9]. Šio darbo tikslas pristatyti du klinikinius VD, sukeltos ilgalaikio antipsichotikų vartojimo, atvejus, kai gydymas buvo sėkmingas, ir pateikti naujausią informaciją apie šią ligą, daugiausia dèmesio skiriant jos gydymui.

\section{KLINIKINIŲ ATVEJŲ APRAŠYMAI}

\section{I klinikinis atvejis}

43 metų amžiaus moteris $2018 \mathrm{~m}$. hospitalizuota ir 65 dienas gydyta VšI Respublikinèje Vilniaus psichiatrijos ligoninejje (RVPL). Pacientè, serganti paranoidine šizofrenija (F20.0), atvyko lydima artimujų, su gydytojo psichiatro siuntimu dèl viso kūno nuolatinių nevalingų judesių.

Pacientė dèl psichikos sutrikimų buvo hospitalizuota 9 kartus. Pirmą kartą dèl psichikos sutrikimo pacientė gydyta 1995 m., kai jai buvo 20 m. Pirmiausia buvo diagnozuotas šizoafektinis sutrikimas, depresijos tipas (F25.1). Po 7 metų diagnozė pakeista ị šizoafektinị sutrikimą, mišrų tipą (F25.2). 2014 m. hospitalizacijos metu diagnozė pakeista ị paranoidinę šizofreniją (F20.0). Hospitalizacijų metu vystėsi negatyvi ir pozityvi simptomatika: komentuojančio pobūdžio klausos haliucinacijos; nuo kliedesinių nuostatų ir įtarumo iki kliedesių prieš motiną, poveikio kliedesių; neadekvačios emocijos, rezonieriškas ir nenuoseklus mąstymas, ambitendentiškumas, manieringumas, minčių atvirumas, baimingumas, agresyvumas, pretenzingumas, apatija, abulija. Pacientė ligos vystymosi pradžioje buvo gydyta medazepamu, perfenazinu, trifluoperazinu, amitriptilinu ir būklè būdavo patenkinama. Vèliau gydyta risperidonu 4-6 mg per parą, vèliau - pailginto atpalaida- vimo risperidonu $25-37,5 \mathrm{mg}$ kas dvi savaites, taip pat klomipraminu, lorazepamu, triheksifenidiliu. $2014 \mathrm{~m}$. hospitalizacijos metu, kai diagnozė buvo pakeista ị paranoidinę šizofreniją (F20.0), jau buvo aprašytas pacientès ryškus defektas visose psichikos sferose, pokalbio metu negalejo išsėdèti ramiai, vis stojosi, kramtė nagus, čepsèjo, kas leidžia galvoti, kad jau buvo prasidejjusios diskinezijos. Buvo paskirtas gydymas paliperidono palmitatu $100 \mathrm{mg}$ į raumenis kas 4 savaites. Paskutinị kartą hospitalizuota 2015 m., stebėti nevalingi kojų judesiai, pacientè nebegalèjusi išbūti vienoje vietoje. Gydymas paliperidonu buvo pakeistas ị gydymą risperidonu, bet nevalingi judesiai išliko. Rekomenduota atlikti galvos magnetinio rezonanso tomografiją (MRT) - tyrime nerasta nieko ypatingo. Skirtas gydymas olanzapinu $20 \mathrm{mg}$ per parą, triheksifenidiliu, klonazepamu - sumažejjo diskineziniai judesiai. Pastaruosius $3 \mathrm{~m}$. iki paskutinès hospitalizacijos pacientė vartojo chlorpromazino $50 \mathrm{mg} 2$ kartus per parą, triheksifenidili, olanzapino $20 \mathrm{mg}$ per parą, klonazepamo $4 \mathrm{mg}$ per parą, tačiau pacientès motina, nematydama dukters sveikatos pagerėjimo, savavališkai ėmė mažinti paskirtų vaistų kieki.

Objektyvios anamnezès duomenimis, artimieji prieš 19 m. pastebejjo pavienius pacientès galvos krestelèjimus, kurie praejjo. Prieš $10 \mathrm{~m}$. pastebėjo rankų drebejjimą, prieš 7-8 m. prasidèjo įvairūs trūkčiojimai - pirmiausia atsirado viršutinès kūno dalies, pečių trūkčiojimai, vẻliau kojų, prasidejo veido grimasos. Judesiai visada buvo panašūs, tik per laiką didejjo judesių amplitudè. Itin ryškiai judesiai išreikšti jau apie dvejus metus. Pacientė pastaruoju metu gyveno su tèvais ir nedirbo, nustatytas $25 \%$ darbingumo lygis, turi specialiuosius poreikius priežiūrai.

Psichikos būsena paskutinès hospitalizacijos metu: ateina keistai įmantria eisena, kiek šoktelėdama, keistai dẻliodama pėdas, sustojus sukryžiuoja kojas, nenustygsta vietoje, nuolat juda, kruta, gausūs įvairūs nevalingi, neritmiški viso kūno judesiai, veidą perkreipia grubios grimasos. Sako, kad neištvers garsų, dangus griūva ir juokiasi, o juoką pakeičia verksmo grimasa. Judesių pagausẻja susijaudinus, keliantis, stojantis. Rankų nagai nukramtyti. Stebima hiperhidrozė. Kalba nenatūralia vaikiška intonacija, pavieniais žodžiais neprasmingai atsakydama ị klausimus. Pasako, kad ,judesiai neteisingi, bijo medžių, žmonių, medžiai tamsūs ir bado, vètros, audros, nežinau“. Pavyksta išgirsti, kad žmonès nedraugiški, kad kaimyną Praną matė su peiliu, ji neina net ị kiemą. Bandant patikslinti, atsako „nenoriu, nepatinka, atsibosta“, dar klausiant, ko bijo, atsako klausimu, „gal jūs žinot?“. Kalbant apie praeitị, sako, kad kadaise girdėjo vyriškus balsus. Apie gydymą sako, kad geria olanzapiną, kad anksčiau švirkštè, gal 30 ampulių, „Rispolept Consta“, paskutinị kartą rugpjūčio pradžioje, bet neteisingai pasako dabartinị mėnesi - tai lapkritis, tai gruodis, galiausiai pasako, kad spalis. Žino, kad antradienis, dieną taip pat pasako teisingai. Žino, kad yra Vilniuje, psichiatrijos ligoninejje. Pasirašant informacijos teikimo lapą, sutikimo lapą gydytis - reaguoja nepatikliai, nenorinti ilgai būti ligoninejje, esanti sveika, čia atsiuntè tèvai, bet pasirašè, nors metus parašè neteisingai - „200018“, 
„20018“, perklausus - kartoja tą patị, prašè pasakyti mėnesị ir dieną.

Somatinè ir neurologinė būklè: pacientė sujaudinta, nuolat juda lovoje, gulèdama sukasi aplink savo ašį, bet neiškrenta. Pacientei kalbant, stebimi trumpi, nevalingi veido viršutinio ir vidurinio aukštų stereotipiniai raumenų susitraukinejjimai (suraukia nosį, užsimerkia), kartais vokalizacijos, liežuvio impersistencija. Veide stebimos asimetriškos raukšlès, grimasos be orofacialinių diskinezijų. Stebimi nepertraukiami generalizuoti greiti, neritmiški, nevalingi, sukamieji, manieringi, stereotipiški distoniniai-hiperkineziniai galūnių ir liemens raumenų judesiai. Čiuopiant raumenis, visų galūnių raumenų tonusas - didelis, o bandant lankstyti galūnes, neatsipalaiduoja, lenkia jas pati. Veido ir kūno judesiai išnyksta, nukreipus dèmesi ị užduoti, o padaugèja emociškai susijaudinus. Pacientė nurodo nežymią hipesteziją kairèje kojoje (ne pagal dermatomus). Refleksai rankose - simetriški, kojose - dešinejje > kairejje. Eina manieringai, mojuoja rankomis, kartais paeina ant pirštų. Kairè koja einant rotuota į vidų, pirštai išskèsti. Lankstant po vaikščiojimo kairès rankos, kairès kojos ir pėdos tonusai yra didesni, o pagulejus sumažèja.

Bendras kraujo, biocheminis kraujo ir bendras šlapimo tyrimai buvo be žymesnių patologinių pokyčių. Atliktas $\mathrm{Cu}(\mu \mathrm{mol} / \mathrm{l})$ koncentracijos serume tyrimas parodè jo sumažejjimą - 11,02 $\mu \mathrm{mol} / 1$ (norma moterims 12,6-24,4 $\mu \mathrm{mol} / 1$ ). Galvos smegenų kompiuterinès tomografijos (KT) tyrime židininių pakitimų galvos smegenyse nestebèta, abipus frontotemporaliai simetrinės atrofijos. Elektroencefalografijos (EEG) tyrimas parodè bendrinius galvos smegenų bioelektrinio aktyvumo nedidelius pakitimus.

Iš pradžių ịtarta, kad pacientė serga distonija, tačiau po trečios neurologo konsultacijos padaryta išvada, kad vyrauja sunkiai klasifikuojami netvarkingi judesiai, ir toliau diferencijuota tarp psichogeninès kilmès judesių, neurometabolinių kaupimo ligų (Vilsono ligos, geležies kaupimo ligos, neuroakantocitozès) ir neuroleptikų sukeltų hiperkinezių. İvertinus ligos anamnezę, objektyvaus ištyrimo duomenis ir instrumentinių tyrimų duomenis, patvirtinta diagnozè - vaistų sukelta distonija (G24.0), t. y. ilgalaikio antipsichotikų vartojimo sukelta vèlyvoji (tardyvinè) diskinezija.

Taikytas gydymas: paranoidinès šizofrenijos simptomams gydyti skirtas olanzapinas, dozè titruota iki $15 \mathrm{mg}$ per parą. Dirglumui ir raumenu įtampai mažinti - klonazepamo $4 \mathrm{mg}$ per parą, vèliau $3 \mathrm{mg}$ per parą. Arteriniam kraujo spaudimui ir tachikardijai mažinti skirta metoprololio $50 \mathrm{mg}$ per parą. Vèlyvosios diskinezijos judesiams gydyti paskirta tetrabenazino $12,5 \mathrm{mg}$ per parą, dozė titruota iki $50 \mathrm{mg}$ per parą. Taip pat taikyta užimtumo terapija.

Stebejjimo išvados: paciente buvo apatiška, nesidomėjo aplinka, neužsiminejjo jokia veikla, dažniausiai gulėdavo lovoje. Nenoromis, paraginta, trumpai pabūdavo skyriaus užsièmimuose, tik raginama nusiprausdavo. Buvo ịsitempusi, baikšti, netvarkinga, susivèlusi, nukramtytais nagais, stebėta ryški hiperhidrozė (gausus prakaitavimas). Kalbejjo vaikiška intonacija, neprasmingai, padrikai, trum-

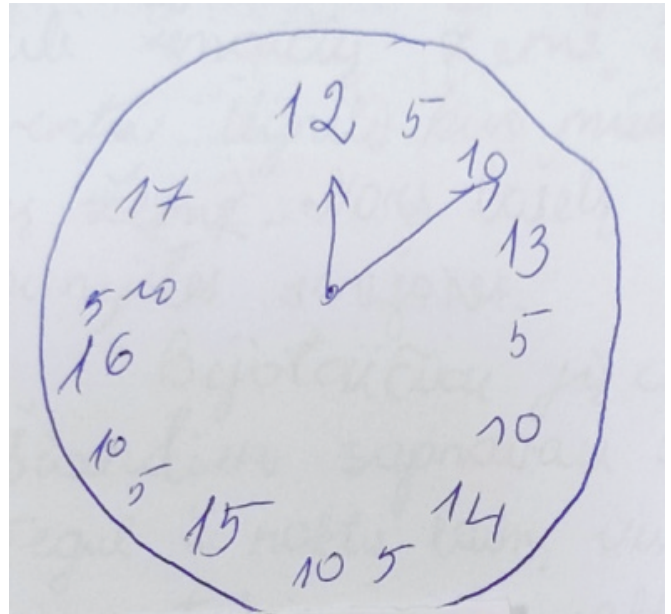

1 pav. Pacientės pieštas laikrodis

pais sakiniais, pavieniais žodžiais atsakydama ị klausimus. Pokalbio su gydytojų konsultacine komisija (GKK) metu buvo paprašyta nupiešti laikrodi - skaičiai buvo išdẻstyti netvarkingai (1, 2 pav.).

Gydant, kraujospūdis normalizavosi, tachikardija kartojosi rečiau. Po tetrabenazino paskyrimo, kaip ir tikètasi, pacientės būklè akivaizdžiai palaipsniui gerejo: eisena tapo natūralesnè, pokalbio metu sėdèjo ramiau, būdingi judesiai išnyko, raumenų tonusas galūnèse tapo normalus, pradejjo nykti raukšlès kaktoje - nebeliko veidą perkreipiančių grimasų, nebeprakaitavo. Stebėtos gyvesnès emocijos, nuotaika „nei gera, nei bloga“. Pacientès dirglumas išnyko, pradèjo kalbẻti rišliai atsakydama ị klausimus, pripažino būsenos pagerẻjimą. Išliko hipobuliška, apatiška, nuolat reikejo raginti eiti pasivaikščioti, daugiausia gulejo palatoje ir paraginus minimaliai veiklai - beveik visada atsisakydavo, o ėmusi veiklos - greitai ją nutraukdavo. Skyriuje priaugo apie $6 \mathrm{~kg}$. Pozityvių ir negatyvių simptomų skalès (PANSS) įvertis gydant sumažėjo nuo 110 iki 91 balo.

Toliau rekomenduota reguliariai lankytis pas apylinkès psichiatrą dèl būklès stebėjimo, vartoti paskirtus vaistus: olanzapino $15 \mathrm{mg}$ per parą, klonazepamo $2 \mathrm{mg}$ per parą, tetrabenazino $50 \mathrm{mg}$ per para, pailginto atpalaidavimo metoprololio $23,75 \mathrm{mg}$ per parą.

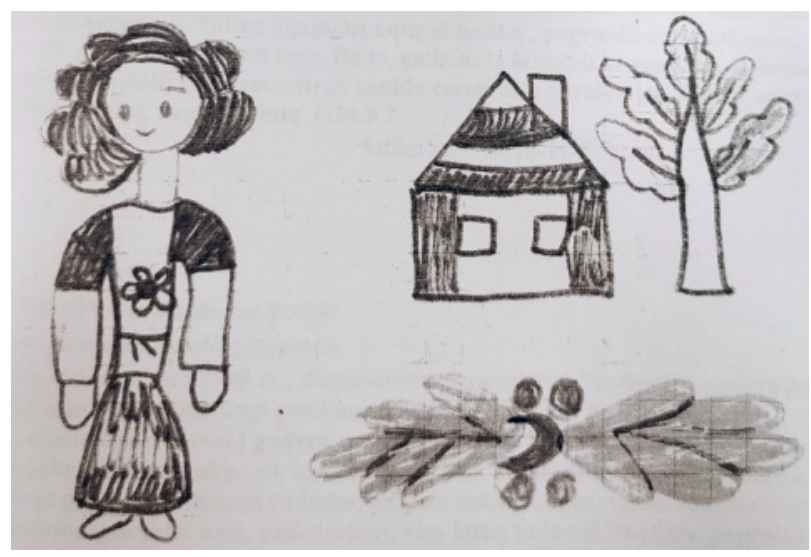

2 pav. Pacientès piešiniai 


\section{II klinikinis atvejis}

55 metų paciente 2019 m. hospitalizuota ir gydyta RVPL 29 dienas. Atvyko su psichiatro siuntimu dèl nevalingų judesių, lydima dukters. Ši paciente RVPL gydyta 8 kartus, pirma hospitalizacija $1982 \mathrm{~m}$., kai pacientei buvo $18 \mathrm{~m}$., dèl ūmios psichozès su nuodijimo, santykio, nuostolio, neištikimybès kliedesiais, ryškiai neadekvačiu ir aplinkiniams pavojingu elgesiu. 5 kartus gydyta priverstinai teismo nutartimi. Gydyta haloperidoliu, diazepamu, zuklopentiksoliu, triheksifenidilio hidrochloridu. Paskutinị kartą hospitalizuota 2009 m., diagnozuotas kliedesinis sutrikimas (F22.0). Po šios hospitalizacijos kas 3 mènesius lankèsi Psichikos sveikatos centre (PSC) ir reguliariai vartojo šiuos vaistus: haloperidolio dekanoato injekcijas $70,52 \mathrm{mg}$ kas dvi savaites, cisordinolio $30 \mathrm{mg}$ per parą, triheksifenidilio $6 \mathrm{mg}$ per parą, mirtazapino (dozè nežinoma). Pacientė gyvena viena, turi dukrą. Nustatytas $30 \%$ darbingumo lygis. Pastaruoju metu namuose nieko neveikdavo, išskyrus šuns vedžiojimą, gulèdavo lovoje, nenorèdavo tvarkytis, skundžiasi niūria nuotaika, apetito praradimu, kad niekas nedomina. Dukters teigimu, kadaise buvę nuodijimo, santykio, nuostolio ir neištikimybès kliedesiai jau apie 10 metų dezaktualizavęsi, o agresyvaus ar neadekvataus elgesio pasireiškimų nestebejjo. Anamnezès duomenimis, prieš 7 metus stebèti neurolepsinio sindromo simptomai - kaklo rigidiškumas, konsultavosi su neurologais ir buvo gydyta botulino injekcijomis, tačiau efekto nebuvo. Vèliau atsirado akatizija, rankų diskinezijos. Pati paciente nebenorejo koreguoti gydymo, konsultuotis su specialistais. Būklè pastaruoju metu nuolat blogèjo. Pastaruosius metus nevalingi judesiai stiprèjo, plito, apėmè rankas ir liemenị. Dèl šių judesių pacientè negalinti išsėdèti, nuolat muistosi, judesiai susilpnejja atsigulus. 3 sav. iki šios hospitalizacijos patyre kolapsa ir buvo konsultuota neurologo. Atliktas galvos smegenų KT tyrimas - ūmi neurologinè patologija atmesta ir išsiaiškinta, kad prieš šį alpimo epizodą pacientė kelias dienas nieko nevalgè, nes neturẻjo apetito. Šios konsultacijos metu pacientė buvo nukreipta ị RVPL.

Psichinè būklè: Sklinda nešvaros kvapas. Kontaktas apsunkintas dẻl gausių, išplitusių nevalingų judesių, dažnai lošiasi, sukasi liemeniu, ištiesia ir sulenkia rankas, judina kojas, suka kaklą (daugiau ị kairę pusę), atlošia galvą. Stebima daug veido grimasų, kalba mikčiodama. Emocijos - neadekvačios, viso pokalbio metu veide sustingusi šypsena. Mąstymas - nuskurdęs, atsakinejja trumpomis frazėmis, pokalbio nepalaiko, aspontaniška. Paciente išsako paralogiškų minčių: bijojusi gultis ị ligoninę, nes čia ją išgydys, bet mano serganti „nervų sistemos sutrikimu“, todèl visus 10 metų nuosekliai vartojusi vaistus, dèl kurių pasireiškę judesių sutrikimai. Santykiai su dukra esantys geri, anksčiau dukra „buvusi bloga“, negrižčdavo nakvoti, laiką leisdavusi su vyrais, „blogai elgdavosi“, daugiau detalizuoti atsisako, tampa gynybiška. Aktyviai skundžiasi tik judesių sutrikimu, tikslingai teiraujantis pasako, kad nieko nesinori, niekas neįdomu, vyrauja liūdna nuotaika, blogas apetitas, kartais visai nevalganti. Suicidines min- tis neigia. Suvokimo sutrikimus neigia, iš elgesio neįtariama.

Somatinè ir neurologinè būklè: AKS 160/100 mmHg, ŠSD - 76 k./min. Oda - prakaituota. Stebimi išplitę nevalingi choreoatetoidiniai judesiai (veido raumenų, kaklo, liemens, abiejų rankų, kiek asimetriškai, daugiau išreikšta kairèje). Pokalbio metu pasiskundžia, kad „sutraukè šlaunies raumenis“, pradejjo masažuoti rankomis. Grubus ištiestų rankų tremoras. Sausgyslių refleksai - simetriški, išgaunami abipus, patologinių refleksų nestebima. Parezių, jutimų sutrikimų nèra, veidinių nervų funkcija nesutrikusi. Nevalingi judesiai ryškesni sèdint, kiek mažesni stovint ar atsigulus. Vidaus organų sistemos - be ūmios patologijos požymių. Rijimo sutrikimų, springimų nèra.

Laboratoriniai tyrimai - be žymesnių nukrypimų.

İvertinus pacientès psichopatologiją - anamnezèje daug kliedesių, stebimi išreikšti mąstymo formos sutrikimai, progresuojanti negatyvi simptomatika, socialinè izoliacija, darbinè dezadaptacija, ligos eiga labiau būdinga paranoidinei šizofrenijai, todèl diagnozuojama paranoidinè šizofrenija (F20.0). Taip pat pastaruosius kelerius metus pasireiškè vèlyvosios diskinezijos reiškiniai (daug metų buvo gydoma dviejų klasikinių antipsichotikų deriniu), dèl ko diagnozuota vaistų sukelta distonija (G24.0).

Pacientei paskirtas gydymas: paranoidinės šizofrenijos simptomams gydyti - klozapino, dozę laipsniškai titruojant iki $200 \mathrm{mg}$ per parą (atliekant kas savaitę bendrą kraujo tyrimą ir stebint leukocitų kiekị dèl galimo nepageidaujamo reiškinio - leukopenijos). Nerimui mažinti ir raumenims atpalaiduoti skirta klonazepamo iki $2 \mathrm{mg}$ per parą. Diskinezijai kupiruoti - tetrabenazino pagal neurologo rekomendacijas iki $25 \mathrm{mg}$ per parą. Taip pat taikyta užimtumo terapija, individuali psichoterapija, šeimos konsultavimas pacientès priežiūros namuose klausimais.

Stebẻjimo išvados: Skyriuje buvo pasyvi, atsiribojusi nuo kitų ligonių, laiką daugiausia leisdavo gulėdama lovoje. Jokia kita veikla neužsiimdavo, tik aktyviai paraginus trumpai sudalyvaudavo užimtumo terapijoje. Veiklą labai ribojo vèlyvosios diskinezijos reiškiniai (choreoatetoidiniai, distoniniai judesių sutrikimai, akatizijos reiškiniai). Pokalbių metu buvo kraštutinai formali, gynybiškai atsakinėdavo ị klausimus apie buvusius psichozinius išgyvenimus, juos vertino nekritiškai. Gydymo metu iš dalies sumažèjo nevalingų judesių amplitudè, galèdavo ramiai pagulèti, savarankiškai pavalgyti, nusiprausti, apsirengti. Labiau žymūs išliko distoniniai judesiu sutrikimai (asimetriški, labiau išreikšti kairèje pusèje). Kliedesiai neišryškejjo, su aplankyti atvykusia dukra bendravo ramiai, be priešiškumo. Išliko blausių, adekvatumo stokojančių emocijų, skurdaus mąstymo, hipobuliška, tekdavo paraginti laikytis higienos. Stebima išreikšta negatyvi simptomatika emocijų, valios, mąstymo sferose, žymus asmenybès defektas. Gydymą toleravo gerai, išskyrus vidutinio intensyvumo hipersalivaciją, kitų šalutinių poveikių nestebèta. Taikytas kraujo monitoringas 1 kartą per savaitę, rodikliai - normalūs, išskyrus nežymų eozinofilų padidejjimą kraujyje. 
Išrašant rekomenduota vartoti klozapino $200 \mathrm{mg}$ per parą, tetrabenazino $25 \mathrm{mg}$ per parą, klonazepamo $2 \mathrm{mg}$ per parą. Taip pat tikslinga neurologo konsultacija ambulatoriškai, tęsti kraujo monitoringą 1 kartą per savaitę 14 savaičių po hospitalizacijos ir vèliau 1 kartą per mẻnesị dèl klozapino vartojimo.

\section{APTARIMAS}

\section{Vèlyvoji diskinezija klinikinëje praktikoje}

Judèjimo sutrikimai, sukelti dopamino receptorių blokatorių, gali būti laikini arba nuolatiniai, išliekantys net nutraukus vaistus. Praeinantys judejjimo sutrikimai: drebulys, mioklonusas, parkinsonizmas, ūminė distoninė reakcija, ūminè akatizija, piktybinis neurolepsinis sindromas. Išliekantis judèjimo sutrikimas būtų vèlyvasis sindromas (angl. tardive syndrome), kuris apima VD ir kitus sutrikimus, tokius kaip parkinsonizmas, eisenos sutrikimai, vèlyvoji distonija, vèlyvoji akatizija ir kt. [2].

Pagal Psichikos sutrikimu diagnostikos ir statistikos vadovo penktą leidimą (DSM-V), VD apibrěžiama kaip „nevalingi atetoidiniai ar choreiforminiai judesiai (trunkantys mažiausiai kelias savaites), paprastai liežuvio, apatinio veido ir žandikaulio bei galūnių (bet kartais įtraukiant ryklès, diafragmos ar liemens raumenis), atsirandantys kartu su neuroleptikų vartojimu mažiausiai keletą mėnesių“ [10]. Klasikinė VD dažniausiai pasireiškia nevalingais veido raumenų ir liežuvio judesiais ir choreoatetoidiniais liemens bei galūnių judesiais, tačiau egzistuoja ir kitos VD formos, kai nevalingi judesiai pasireiškia ịvairiose kūno vietos [11]. Standartinè diskinezijos vertinimo priemonė yra nenormalių nevalingų judesių skalè (angl. $A b-$ normal Involuntary Movement Scale, AIMS), vertinanti diskinezinius judesius 7-iose kūno srityse nuo 0 iki 4 balu ( 0 - nèra, 1 - minimalūs diskineziniai judesiai; 2 - lengvi diskineziniai judesiai; 3 - vidutinio sunkumo diskineziniai judesiai; 4 - sunkūs diskineziniai judesiai) [3, 12]. VD diagnozuoti galima, kai išpildomi 3 Schooler-Kane kriterijai: pirmas - mažiausiai 3 ménesius vartojami dopaminą blokuojantys vaistai, antras - vidutinio sunkumo diskineziniai judesiai pagal AIMS - vienoje kūno srityje arba lengvi diskineziniai judesiai pagal AIMS - keliose kūno srityse, trečias - kitų nevalingų judesių priežasčių atmetimas [13].

Veiksniai, didinantys riziką susirgti VD, yra vyresnis amžius, moteriška lytis, baltaodžių ar afroamerikiečių rasè, ilgesnè ligos trukmè, pažintinių funkcijų pablogèjimas, šizofrenija, nuotaikos sutrikimai [14].

\section{Etiologija}

VD paplitimas yra didesnis, nei ịprastai suvokiama. Nuo tada, kai klinikinejje praktikoje pradèti naudoti antros kartos antipsichotikai, paskelbta nemažai publikacijų apie VD dažnị ir paplitimą. Naujausi duomenys rodo, kad VD dažnis, naudojant antros kartos antipsichotikus, yra didesnis nei buvo pranešta anksčiau [15]. Neseniai atliktoje metaanalizejje nustatyta, kad VD paplitimas tarp pacientu, gydomų bet kokiais antipsichoziniais vaistais, yra 25,3\% [4]. Correll ir Shenk atliktoje apžvalgoje buvo 12 tyrimų, paskelbtų 2004-2008 m., kuriuose dalyvavo 30129 pacientai. Šis tyrimas parodè, kad metinis VD dažnis, vartojant pirmos kartos antipsichozinius vaistus, $-5,5 \%$, o vartojant antros kartos antipsichozinius vaistus - 3,9\% [16]. Atliktoje metaanalizèje, sudarytoje iš 41 tyrimo, kurioje dalyvavo daugiau nei 11000 pacientų, kurių vidutinis amžius 43 metai, bendras VD paplitimas imtyje buvo $25 \%$. VD dažnis buvo mažesnis tarp pacientų, vartojančių antros kartos antipsichotikus, palyginti su pacientais, vartojančiais pirmos kartos antipsichotikus, - atitinkamai $21 \%$ ir $30 \%$. Nedidelé dalis pacientų, kurie esamuoju laiku vartojo antros kartos antipsichotikus be ankstesnio pirmos kartos antipsichotikų vartojimo, paplitimas buvo tik 7,2 \% [4]. Atipinių antipsichotikų vartojimas siejamas su mažesne VD rizika, tačiau visi antipsichotikai, veikiantys kaip DRB, gali sukelti VD [17]. Tai aiškinama mažesniu atipinių antipsichotikų afinitetu, lyginant su tipiniais antipsichotikais, dryžuotojo kūno nugarinèje dalyje esantiems dopamino D2 receptoriams, taip pat antagonistiniu poveikiu serotonino 5-HT2A/2C receptoriams ir trumpesniu prisijungimo prie $\mathrm{D} 2$ receptorių laikotarpiu, t. y. 12-24 valandos, lyginant su kelių dienų atipinių antipsichotikų atveju $[17,18]$.

\section{Patofiziologija}

VD patofiziologijoje trūksta visuotinai pripažintos teorijos. Nors buvo pasiūlyta daugybė teorijų su didele paaiškinamaja verte, tikslus VD mechanizmas nèra suprastas [1]. Dopamino blokada yra pagrindinis žinomas VD sukeliantis veiksnys, tačiau yra daugiau faktorių, kurie daro ịtaką VD išsivystymui. Manoma, kad VD pasireiškia dèl motorinių neuronų nigrostriatiniame take pažeidimo [19]. Siūlomos hipotezès apima ilgesni postsinapsinių dopamino receptorių blokavimą, sukeliantị padidèjusị dopamino receptoriu jautrumą, gama amino sviesto rūgšties (GABA) išsekimą, cholinerginį trūkumą, oksidacinị stresą, pakitusi sinapsini plastiškumą, neurotoksiškumą ir ydingą neuroadaptyvų signalizavimą [20]. Naujausiais duomenimis, svarstant ịvairias VD patofiziologijos teorijas, galima ịtarti, kad VD gali atsirasti dèl presinapsinių, sinapsinių ir postsinapsinių pokyčių derinio. Dažniausiai literatūroje sutinkama teorija aiškina, kad lètinè dopamino D2 receptorių blokada sukelia kompensacini postsinapsinių dopamino receptorių jautrumą dèl padidèjusio dopamino receptorių skaičiaus ir (ar) reagavimo. Yra aiškių įrodymų, kad padaugeja postsinapsinių dopamino D2 receptorių, nors nèra ịrodymų, kad padidèja šių receptoriu jautrumas [21]. Taigi ši teorija reprezentuoja būtent postsinapsinių dopamino receptorių pokyčius. Taip pat manoma, kad padidèja ir pačių sinapsių skaičius dopaminerginèje sistemoje. Tai irodyta stebint padidejusius dendritinius spyglius ir ,perforuotas sinapses", kurios yra laikomos raidos arba plastiškumo pirmtakais naujoms sinapsėms. Didejjant sinapsių 


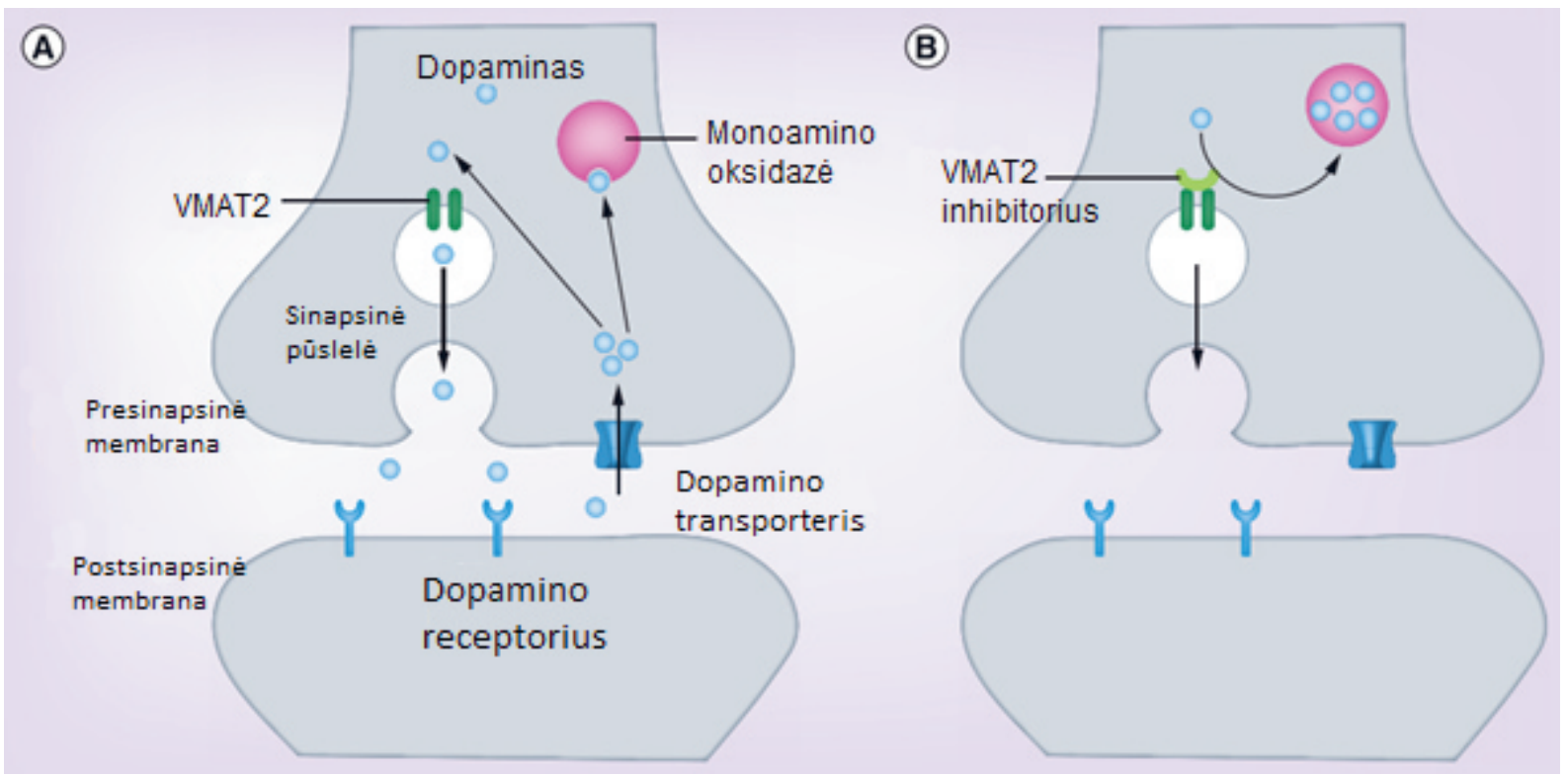

3 pav. VMAT2 inhibitorių veikimo mechanizmas sinapsiniame plyšyje [22]

skaičiui, padidejja dopamino signalo stiprumas, kuris vis dèlto būna nuslopintas dèl vykdomos dopamino receptorių blokados, kai skiriami DRB. Kalbant apie presinapsinius pokyčius, esant didelei postsinapsinei D2 blokadai sinapsẻje, gali būti nesurišto dopamino, kuris dèl padidejjusios dopamino reabsorbcijos gali lemti kiekybini presinapsini padidejjimą [21]. Šis presinapsinis mechanizmas yra tiesiogiai sprendžiamas šiuo metu turimais vezikulinių monoamino transporterių 2 (angl. Vesicular Monoamine Transporter 2, VMAT2) inhibitoriais. Tai gali paaiškinti jų terapini poveikị, net kai postsinapsine D2 blokada nesugeba užblokuoti diskinezinių judesių (3 pav.) [22]. Taigi, turint omeny tokị aiškinimo modelị, kad VD atsiranda dèl keliu skirtingų, bet susijusių procesų, galima numanyti, jog viena intervencija negali užtikrinti visiškos remisijos.

\section{Gydymas}

Siekiant sumažinti VD riziką, labai svarbu kruopščiai atrinkti pacientus, kurie bus gydomi DRB. Nors gali būti sunku visiškai neskirti antipsichozinių vaistų, gydant pacientus, patiriančius psichozę, reikia apsvarstyti skirti vaistus, kurie kelia mažesnę VD išsivystymo riziką. Taip pat svarbu vaistus pradèti vartoti mažomis dozėmis, kruopščiai juos titruojant. Ilgalaikis DRB vartojimas turètų būti ribotas, o pacientus, kurie gydosi DRB, reikia stebėti dẻl ankstyvų VD požymių [17]. Visgi, jei įmanoma, akivaizdus sprendimas yra nutraukti VD sukèlusius DRB, tačiau, staiga nutraukus vartoti vaistą, gali atsirasti nutraukimo simptomų, sustiprinančių VD [23]. Taigi, prieš pradedant vartoti antipsichotikus ar kitus VD sukeliančius vaistus, gydytojai pirmiausia turètų su pacientais aptarti galimą riziką ir paskirti vaistus mažiausia įmanoma doze bei turinčius mažiausią tikimybę sukelti VD.

Vienas iš sunkumų, gydant VD, yra poreikis tęsti tuos pačius vaistus, kurie ir sukèlè VD. Ko gero, pacientas mieliau gyventų su VD simptomais, jei jos kaltininkas antipsi- chotikas tuo pačiu metu kontroliuotų pozityviuosius šizofrenijos simptomus. 2017 m. rekomendacijų siūloma bendra VD valdymo strategija būtų palaipsniui pakeisti pirmos kartos antipsichotikus i antros kartos antipsichotiką olanzapiną, kvetiapiną, risperidoną (išskyrus klozapiną), ir nutraukti bet kokius anticholinerginius vaistus. Svarbu paminèti, kad, staiga nutraukus antipsichotikų skyrimą, VD gali sustiprèti. Jei VD nepagereja, bandoma pereiti prie kito antros kartos antipsichozinio vaisto (išskyrus klozapiną), o jei ir tai nepavyksta, rekomenduotina pereiti prie klozapino [5]. Nors kiti šaltiniai klozapiną išskiria kaip pirmo pasirinkimo antipsichotiką, gydant VD ir esant poreikiui tęsti antipsichozinių vaistų vartojimą, irodymai dẻl jo pranašumo yra nepakankami $[1,24]$. Jei, optimizavus gydymą antipsichoziniais vaistais, VD išlieka didele problema, reikètų apsvarstyti papildomus specifinius vaistus. Yra daug duomenų apie klinikiniuose tyrimuose nagrinèjamus vaistus, skirtus gydyti VD. Beveik visose šių tyrimų apžvalgose ir metaanalizėse padaryta išvada, kad daugumos šių vaistų veiksmingumo įrodymai išlieka preliminarūs ir nepakankami. Nors dauguma vaistų ir nepripažinti efektyviais dèl duomenų trūkumo, kai kurie jų visgi gali būti veiksmingi daliai pacientų, sergančių VD, tad būtų tikslinga atlikti išsamesnius tyrimus [25].

\section{VMAT inhibitoriai}

Tarp perspektyviausių būdų VD gydyti yra VMAT inhibitoriai. Šių receptorių slopinimas sukelia selektyvų, grįžtamajji monoaminų išsekimą terminaliniuose nervuose [1]. Devintojo dešimtmečio viduryje tapo aišku, kad integruoti membranos transporteriai yra būtini neuromediatoriams kaupti sinapsinėse presinapsinių neuronų pūslelèse [26]. Šis atradimas leido apibūdinti kelis vezikulinius transporterius, įskaitant specifiškus acetilcholinui arba monoaminams, tokiems kaip dopaminas, serotoninas, noradrenalinas, adrenalinas ir histaminas [27]. Buvo nustatyta, kad VMAT egzistuoja dviejose izoformose (VMAT1 ir 
VMAT2), kurių pasiskirstymas skiriasi: VMAT1 daugiausia ekspresuojamas periferineje nervu sistemoje, o VMAT2 - daugiausia monoaminerginèse CNS ląstelèse [28].

\section{Tetrabenazinas}

Tetrabenazinas yra VMAT2 inhibitorius, 2008 m. patvirtintas Hantingtono ligai gydyti [29]. Tetrabenazinas buvo sukurtas 1950-aisiais kaip antipsichozinis preparatas, pagrịstas in vivo tyrimais [30]. Pirmasis VD tyrimas su tetrabenazinu buvo paskelbtas $1972 \mathrm{~m}$. [31]. Nuo to laiko buvo paskelbta daugybė tyrimų, îskaitant atvejų ir jų serijų aprašymus, perspektyvinius tyrimus. Nors sunku palyginti tyrimo rezultatus dèl didelių dizaino ir rezultatų skirtumų, didžioji dauguma parodè statistiškai ir kliniškai reikšmingą VD simptomų pagerẻjimą 25-100\% tirtų pacientų, rezultatai svyravo nuo simptomų sunkumo sumažejjimo iki visiškos remisijos [29].

Tetrabenazino metabolitai yra stiprūs selektyvūs VMAT2 inhibitoriai, todèl sumažina presinapsinị dopamino kaupimąsi ir išsiskyrimą. Presinapsinius monoaminus metabolizuoja monoamino oksidazè (MAO), dẻl ko išsenka monoaminų, ypač dopamino, sinapsinis susikaupimas. Taigi tetrabenazinas daugiausia veikia kaip vaistas, mažinantis dopamino koncentraciją sinapsiniame plyšyje. Tetrabenazino sukeliami šalutiniai poveikiai gali būti parkinsonizmas, depresija, akatizija ir mieguistumas. Kadangi VD pasireiškia pacientams, kurie jau turi psichiatrinių ligu anamnezejje, ypač nerimaujama dėl galimos depresijos rizikos, vartojant tetrabenaziną. Tetrabenazino sukeltą depresiją galima suvaldyti ne tik sumažinant tetrabenazino dozę, bet ir kartu vartojant antidepresantus [17].

Tiriant tetrabenazino metabolizmą, paaiškejjo, kad šis greitai ir ekstensyviai virsta 2 izomerais - $\alpha$-dihidrotetrabenazinu (DH-TBZ) ir $\beta$-DH-TBZ, kurie pasizymi dideliu afinitetu VMAT2 ir yra farmakologiškai aktyvūs preparatai [32]. Taigi, tetrabenazinas greitai metabolizuojamas, todèl turi būti dažnai vartojamas [33]. $\alpha$-DH-TBZ izomeras metabolizuojamas per citochroma P450 (CYP) 2D6 ir $3 \mathrm{~A} 4$ ị neaktyvius metabolitus, o $\beta$-DH-TBZ metabolizuojamas tik CYP 2D6. Del trumpo DH-TBZ pusinès eliminacijos periodo ir 2D6 polimorfizmų, Hantingtono ligai gydyti tetrabenaziną rekomenduojama vartoti tris kartus per parą ir nustatyti CYP 2D6 genotipus, kad būtų galima nuspèti prastą metabolizaciją, kai viršijama $50 \mathrm{mg}$ per parą dozè. Norint išvengti šių problemų, buvo ištirtos 2 skirtingos farmakologinès strategijos, skirtos sušvelninti tetrabenazino metabolizmą, leisti vartoti dozes vieną kartą per dieną ir pagerinti toleravimą [9]. Taip naujausi tyrimai sutelkè dėmesị ị du naujus junginius - deutetrabenaziną ir valbenaziną, VMAT2 inhibitorius, kurie pasižymi geresniu toleravimu ir ilgesniu pusinès eliminacijos laiku nei tetrabenazinas [34].

\section{Valbenazinas}

Identifikavus didžiausią VMAT2 afinitetą turinčius tetrabenazino izomerus, buvo išvystytas valbenazinas - provaistas, kuris metabolizuojamas ị aktyviausius dihidrotetrabenazino izomerus. Valbenazinas buvo sukurtas taip, kad būtų lètai metabolizuojamas - mažesnis koncentracijos pikas plazmoje, mažesnis santykis tarp didžiausios ir mažiausios koncentracijų ir mažesnis pasireiškimo kintamumas. Aktyvių metabolitų koncentracijos pikas plazmoje pasiekiamas per 4-10 valandų, o pusinès eliminacijos laikas yra maždaug 20 valandų, leidžiant dozes vartoti kartą per parą [12].

Šis VMAT 2 inhibitorius yra pirmasis FDA patvirtintas vaistas VD gydyti [1]. Neseniai atlikto atsitiktinių imčių, dvigubai aklo, placebu kontroliuojamo tyrimo metu pastebėta, kad, gydant valbenazinu, statistiškai reikšmingai sumažèjo VD simptomai, priklausomai nuo dozès. Pacientų, gydytų didžiausia eksperimentine paros doze (80 mg per parą), per 6 savaites AIMS balai sumažèjo 3,1, palyginti su 0,1 placebo grupeje. Pranešama, kad vaistas buvo gerai toleruojamas, dažniausiai pasireiškiantys šalutiniai poveikiai buvo mieguistumas, akatizija ir burnos džiūvimas [35]. I klasės 6 savaičių dvigubai aklo, placebu kontroliuojamo atsitiktinių imčių tyrimo duomenys parodè, kad vartojančiujų valbenaziną grupejje AIMS balai sumažejjo vidutiniškai 3,6 balo, o $76 \%$ tiriamujuc pasiekè didžiausią leistiną dozę - $75 \mathrm{mg}$ per parą [12]. Kitame I klasės 6 savaičių tyrime (KINECT 3), pagal panašų planą, dalyvavo 234 pacientai, sergantys VD, ir buvo atsitiktinai parinkti vartoti placebą arba nustatytą dozę valbenazino. Valbenazino poveikis reikšmingai sumažino AIMS balus, lyginant su placebu [36]. Gydymas valbenazinu buvo susijęs su mieguistumu, nuovargiu, galvos skausmu, sumažėjusiu apetitu ir galimai pailgèjusiu QT intervalu, tačiau nebuvo duomenų, leidžiančių manyti, kad pacientams, sergantiems šizofrenija, šizoafektiniu sutrikimu ar nuotaikos sutrikimu, pablogèjo depresijos simptomai ar kilo minčiu apie savižudybę. Pradinė valbenazino dozė yra 40 mg kartą per parą, jo reikia vengti pacientams, kuriems yra aritmija, susijusi su pailgejusiu QT intervalu [34].

\section{Deutetrabenazinas}

Deuteruota tetrabenazino forma - deutetrabenazinas buvo susintetintas, atsižvelgiant ị tai, kad, pakeitus tam tikrus vandenilio atomus tetrabenazino molekuleje i jo izotopac deuteri, deutatrabenazino molekulès farmakodinamika nesikeičia, bet keičiasi farmakokinetika. Anglies ir deuterio kovalentiniam ryšiui nutraukti reikia 8 kartus daugiau energijos, nei anglies ir vandenilio ryšiui. Taigi susidarę aktyvūs deutetrabenazino metabolitai išlaiko afinitetą VMAT2, o vandenilio pakeitimas deuteriu konkrečiose vietose labai sulètina metabolitų suskaidymą, todèl farmakokinetinis profilis pasižymi ilgesniu metabolitų veikimo laiku ir didesniu aktyvaus vaisto poveikiu. Be to, deutetrabenazinas turi mažiau įtakos CYP 2D6 izofermento metabolizuojamiems vaistams, todèl nereikalingas genotipavimas, kuris paprastai yra rekomenduojamas pacientams, vartojantiems daugiau kaip $50 \mathrm{mg}$ tetrabenazino per parą [22]. Tai yra antras FDA patvirtintas vaistas VD gydyti [37].

Dviejuose I klasės atsitiktinių imčių, dvigubai akluose, placebu kontroliuojamuose tyrimuose buvo ịvertintas deutetrabenazino poveikis pacientams, sergantiems VD, verti- 
nant AIMS pokytị [38, 39]. Abiejuose tyrimuose buvo leista tęsti vaistus nuo psichozès. Pirmajame tyrime buvo lyginamas deutetrabenazinas ir placebas 117 pacientų, sergančių vidutinio sunkumo ar sunkia VD. Tiriamiesiems buvo atsitiktinai paskirtas 12 savaičių gydymas deutetrabenazinu arba placebu [38]. Pacientams, sergantiems VD ir vartojantiems deutetrabenaziną, AIMS balai sumažèjo reikšmingai, palyginti su tais, kurie vartojo placebą. Kitas III fazès Europos ir JAV daugiacentris, dvigubai aklas, placebu kontroliuojamas tyrimas vertino deutetrabenazino veiksmingumą, vartojant fiksuotas skirtingas dozes. 298 pacientams, sergantiems VD, stebėti reikšmingi AIMS balų sumažèjimai, palyginti su placebu [39]. Abiejuose tyrimuose deutetrabenazinas buvo gerai toleruojamas, tarp tiriamuju grupių buvo panašios nepageidaujamos reakcijos. Deutetrabenazino III fazès rezultatai parodè sumažejusị depresijos, mieguistumo ir akatizijos lygi, palyginti su tetrabenazino tyrimų rezultatais. Pradinè deutetrabenazino dozė yra $6 \mathrm{mg}$ karta per parą [34]. Deutetrabenazinas kontraindikuotinas vartoti pacientams, kurie turi polinkị savižudybei, serga negydyta depresija, turi kepenų funkcijos sutrikimų ar vartoja monoaminooksidazès inhibitorius [34].

Remiantis dviem I klasès tyrimais, tiek deutetrabenazinas, tiek valbenazinas yra veiksmingi gydant VD (A lygis). Pacientams, kurie neturi galimybės gauti deutetrabenazino ar valbenazino, reikètų galvoti apie tetrabenaziną. Tetrabenazino rekomendacija yra Clygio, kas rodo, kad jis gali būti veiksmingas gydant VD [34]. Tetrabenazinas yra registruotas Lietuvos Respublikos vaistinių preparatų registre, o deutetrabenazinas ir valbenazinas - ne. Lietuvoje tetrabenazino vaistinio preparato pavadinimas yra „Tetmodis“, gamintojas - „Orpha-Devel Handels und Vertriebs“. Vienoje tabletėje yra $25 \mathrm{mg}$, pakuotejje - 112 tablečių, šis vaistas šiuo metu kompensuojamas 100 \% tik Hantingtono ligai gydyti [40].

\section{Amantadinas}

Iš pradžių patvirtintas kaip antivirusinis vaistas, amantadinas yra NMDA (N-metil-D-asparto rūgštis) receptorių blokatorius, turintis JAV maisto ir vaistų administracijos (angl. Food and Drug Administration, FDA) patvirtinimą Parkinsono ligai gydyti. Manoma, kad jis veikia sužadinamuosius glutamaterginius takus blyškiojo kamuolio ( $\mathrm{glo}$ bus pallidus) srityje, kurie reguliuoja judesius [1]. Apie galimą amantadino naudą, gydant VD, pirmą kartą pranešta $1971 \mathrm{~m}$. Vienintelis tyrimas, atliktas per pastaraji dešimtmeti, buvo placebu kontroliuojamas, dvigubai aklas, kryžminis tyrimas, kuriame dalyvavo 22 pacientai, vartojantys amantadiną kartu su antipsichotikais. Po dviejų savaičiu gydymo buvo pastebėtas $21,81 \%$ pagerejimas vartojant amantadiną pagal AIMS, palyginti su placebu [41].

\section{Ginkmedžio lapų ekstraktas}

Ginkmedžio lapų ekstraktas yra antioksidantas, pasižymintis savybe neutralizuoti laisvuosius radikalus. 12 savaičių dvigubai aklo, placebu kontroliuojamo tyrimo metu tirtas ginkmedžio lapų ekstrakto poveikis šizofrenija ir VD sergantiems pacientams. $51 \%$ pacientų, vartojusių ginkmedžio lapų ekstraktą, sumažèjo AIMS balai, palyginti su $5 \%$ pacientų, vartojusių antipsichozinius vaistus ir placebo [42]. Atlikus ankstesnio tyrimo metaanalizę kartu su atvirais ir vienpusiai aklais tyrimais, paaiškejo, kad ginkmedžio lapų ekstraktas kartu su antipsichoziniu gydymu labai sumažino AIMS balus, palyginti su placebu [43].

\section{Klonazepamas}

GABA-erginiai vaistai teoriškai galètų palengvinti VD simptomus, padidindami GABA aktyvumą nigrostriatiniame take. Seniai buvo atliktas vienas nedidelis dvigubai aklas, placebu kontroliuojamas klinikinis tyrimas, kurio metu buvo tiriamas klonazepamas, gydant VD. Po 12 savaičių tyrimo klonazepamu gydytų grupejje diskinezijos simptomai pagerejo $35 \%$ tiriamujų. Vèliau šis poveikis buvo prarastas tiems, kurie tęsè atvirajị tyrimo etapą [44].

\section{Propranololis}

Propranololis yra beta adrenerginių receptorių antagonistas, vartojamas akatizijai, aukštam kraujospūdžiui, širdies ritmo sutrikimams ir migrenai gydyti. Retrospektyvinis 47 pacientų, sergančių VD, tyrimas, kuris tęsèsi 17 mėnesių po antipsichotikų nutraukimo, parodè, kad maža propranololio dozè šioje pacientų grupejje buvo gerai toleruojama ir $64 \%$ pacientų pastebėjo savo simptomų pagerẻjimą [45].

\section{Piracetamas ir levetiracetamas}

Duomenų, patvirtinančių levetiracetamo vartojimą, gydant VD, nepakanka. Nepaisant to, keli atviri klinikiniai tyrimai ir klinikinių atvejų aprašymai įrode, kad piracetamas ir jo struktūrinis analogas levetiracetamas pagerina VD simptomus. Paskutinis klinikinis tyrimas apie piracetamą buvo devynių savaičių dvigubai aklas kryžminis tyrimas, paskelbtas 2007 m. Rezultatai parode, kad pagerejjo $67 \%$ pacientų VD simptomai, kai piracetamas buvo pridètas prie esamo gydymo nuo psichozès, palyginti su $24 \%$ pacientų, vartojusių placebą [46]. Dèl levetiracetamo iki šiol atliktus tyrimus sudaro daugiausia atvejų aprašymai, atviri tyrimai ir vienas 12 savaičių dvigubai aklas atsitiktinių imčių kontroliuojamas tyrimas. Jis parodẻ reikšmingą VD simptomų sumažèjimą, vartojant levetiracetamą, tačiau nebaigusių tyrimo buvo daugiau nei $20 \%$ [47].

\section{Kiti vaistai}

Iki šiol turimi ịrodymai nėra galutiniai, kad būtų galima pateikti konkrečias rekomendacijas dèl klonidino, šakotosios grandinès aminorūgščių, nepakeičiamų riebalų rūgščių, ličio, zolpidemo, MAO-B inhibitorių, $\alpha$-antagonistų, baklofeno, bromokriptino ir katecholaminerginių vaistų vartojimo [1]. Buvo ištirti antioksidantai ir vitaminas $\mathrm{E}$, tačiau gauti prieštaringi duomenys apie jų naudą, gydant VD. Iš pradžių vitaminas E mažų klinikinių atvejų serijoje aprašytas kaip turintis teigiamą efektą VD, tačiau didesnių kontroliuojamų tyrimų metu šios išvados nepavyko pakartoti [17]. Remiantis iki šiol atliktais tyrimais, eikozapentaeno rūgštis (EPA) greičiausiai yra neveiksminga, gydant VD. Tikètina, kad melatoninas, vartojamas po $10 \mathrm{mg}$ per parą, yra veiksmingas, tačiau ịrodymai vẻlgi buvo prieštaringi. Kalcio kanalų blokatoriaus nifedipino vartojimo ịrodymai taip pat vis dar riboti. Tyrimai apie diltiazemą neparodė jo- 
kio diskinezijos pagerėjimo, vartojant ši vaistą. Duomenų apie buspirono vartojimą taip pat nepakanka $[1,48]$.

\section{Botulino toksino injekcijos}

Keliuose klinikinių atvejų aprašymuose ir nedideliuose tyrimuose pastebėtas botulino toksino injekcijų veiksmingumas, gydant VD. Šis gydymas yra ypač naudingas pacientams, turintiems židininę ar segmentinę vèlyvają distoniją [11].

\section{Gilioji smegenų stimuliacija}

Gilioji smegenų stimuliacija globus pallidus interna srityje yra skirta mediciniškai atspariai ir sunkiai VD (C lygio rekomendacija) [34]. Literatūroje aprašyta daugiau kaip 70 giliosios smegenų stimuliacijos globus pallidus interna srityje atvejų ir jų serijų, kurių daugelis parode $50 \%$ ilgalaiki simptomų pagerejjimą pagal standartizuotas vertinimo skales. Efektas pasireikšdavo iškart arba per 6 mėnesius ir poveikis buvo ilgalaikis [49].

\section{IŠVADOS IR PASIŪLYMAI}

Apibendrinant visus įrodymus, praktinis gydymo algoritmas siūlo pirmiausia nustatyti, ar pacientui reikalingi antipsichoziniai vaistai, po to ịvertinti diskinezijos sindromo sunkumą. Gydymas turètų būti taikomas, kai negalia yra vidutinio sunkumo ar sunki ir trukdo atlikti kasdienius darbus bei yra suprastejusi gyvenimo kokybė. Pirmiausia reikètų klasikinius antipsichotikus keisti atipiniais, nutraukti vartoti anticholinerginius vaistus (jei tokie buvo skiriami) ir skirti naujus VMAT2 inhibitorius arba tetrabenaziną (jei deutetrabenazinas ir valbenazinas neprieinami). Kadangi Lietuvoje iš VMAT2 inhibitorių prieinamas tik tetrabenazinas, jis ir buvo skirtas abiem pacientėms aprašytuose klinikiniuose atvejuose. Antro pasirinkimo vaistai būtų klonazepamas ir ginkmedžio lapų ekstraktas, derinami su amantadinu, jei simptomai vis dar kelia nerimą. Gilioji smegenų stimuliacija globus pallidus interna srityje turètų būti paliekama neịveikiamai VD [34]. Norint pateikti patikimas, įrodymais pagrịstas terapines rekomendacijas, reikia atlikti daugiau tyrimų, patikrinti perspektyvių vaistų veiksmingumą kontroliuojamuose tyrimuose, kuriuose dalyvautų daugiau pacientų ir būtų vienodesnès sąlygos.

Antipsichotikai plačiai naudojami gydant šizofreniją, bipolinị afektinị sutrikimą, todèl VD išliks klinikine šiuolaikinės psichiatrijos dalimi. Atgimęs susidomėjimas VD paskatino vertingas patofiziologijos ir valdymo mechanizmų įžvalgas. Gydant lètines ir nuolatines psichikos ligas, VD yra problema, kuri akivaizdžiai nėra dingusi ir neturètų būti pamiršta. Kai ši būkle buvo atpažinta daugiau nei prieš 50 metų, buvo greitai pradėti gydyti skirtų vaistų tyrimai, tačiau darbas vyko lètai ir duomenų vis dar trūksta. 2017 m. JAV maisto ir vaistų administracija patvirtino pirmuosius du VD vaistus ir tai yra didžiulis postūmis šioje srityje. Kadangi atsiranda vis daugiau informacijos, stengiamasi išsiaiškinti VD priežastis, reikia tikètis, kad vieną dieną pasirodys tikslingesni vaistai, galintys užkirsti kelią šios ligos atsiradimui arba ją pašalinti.

\section{Literatūra}

1. Witter DP, Holbert RC, Suryadevara U. Pharmacotherapy for the treatment of tardive dyskinesia in schizophrenia patients. Expert Opin Pharmacother 2017; 18(10): 965-72. https://doi.org/10.1080/14656566.2017.1323874

2. Caroff SN, Aggarwal S, Yonan C. Treatment of tardive dyskinesia with tetrabenazine or valbenazine: a systematic review. J Comp Eff Res 2017; 7(2): 135-48. https://doi.org/ 10.2217/cer-2017-0065

3. Correll CU, Kane JM, Citrome LL. Epidemiology, prevention, and assessment of tardive dyskinesia and advances in treatment. J Clin Psychiatry 2017; 78(8): 1136-47. https://doi.org/10.4088/JCP.tv17016ah4c

4. Carbon M, Hsieh C-H, Kane JM, Correll CU. Tardive dyskinesia prevalence in the period of second-generation antipsychotic use: a meta-analysis. J Clin Psychiatry 2017; 78(3): e264-78. https://doi.org/10.4088/JCP.16r10832

5. Citrome L. Clinical management of tardive dyskinesia: five steps to success. J Neurol Sci 2017; 383: 199-204. https://doi.org/10.1016/j.jns.2017.11.019

6. Savitt D, Jankovic J. Tardive syndromes. J Neurol Sci 2018; 389: 35-42. https://doi.org/10.1016/j.jns.2018.02.005

7. Rosenheck RA. Evaluating the cost-effectiveness of reduced tardive dyskinesia with second-generation antipsychotics. $\mathrm{Br}$ J Psychiatry 2007; 191(3): 238-45. https://doi.org/10.1192/ bjp.bp. 106.035063

8. Caroff SN, Yeomans K, Lenderking WR, Cutler AJ, Tanner CM, Shalhoub H, et al. RE-KINECT: a prospective study of the presence and healthcare burden of tardive dyskinesia in clinical practice settings. J Clin Psychopharmacol 2020; 40(3): 259-68. https://doi.org/ 10.1097/JCP.0000000000001201

9. Meyer JM. Forgotten but not gone: new developments in the understanding and treatment of tardive dyskinesia. CNS Spectr 2016; 21(S1): 13-24. https://doi.org/10.1017/ S1092852916000730

10. American Psychiatric Association. Diagnostic and statistical manual of mental disorders (DSM-5). 5th ed. Washington DC: American Psychiatric Association, 2013; 947. https://doi.org/10.1176/appi.books.9780890425596

11. Waln O, Jankovic J. An update on tardive dyskinesia: from phenomenology to treatment. tremor and other hyperkinetic movements. Tremor Other Hyperkinet Mov 2013; 3: tre-03-161-4138-1. https://doi.org/10.5334/tohm.165

12. O'Brien CF, Jimenez R, Hauser RA, Factor SA, Burke J, Mandri D, et al. NBI-98854, a selective monoamine transport inhibitor for the treatment of tardive dyskinesia: a randomized, double-blind, placebo-controlled study. Mov Disord 2015; 30(12): 1681-7. https://doi.org/10.1002/mds.26330

13. Schooler NR, Kane JM. Research diagnoses for tardive dyskinesia. Arch Gen Psychiatry 1982; 39(4): 486-7. https://doi.org/10.1001/archpsyc.1982.04290040080014

14. Solmi M, Pigato G, Kane JM, Correll CU. Clinical risk factors for the development of tardive dyskinesia. J Neurol Sci 2018; 389: 21-7. https://doi.org/10.1016/j.jns.2018.02.012

15. Lerner PP, Miodownik C, Lerner V. Tardive dyskinesia (syndrome): current concept and modern approaches to its management. Psychiatry Clin Neurosci 2015; 69(6): 321-34. https://doi.org/10.1111/pcn.12270

16. Correll CU, Schenk EM. Tardive dyskinesia and new antipsychotics. Curr Opin Psychiatry 2008; 21(2): 151-6. https://doi.org/10.1097/YCO.0b013e3282f53132 
17. Vijayakumar D, Jankovic J. Drug-induced dyskinesia, part 2: treatment of tardive dyskinesia. Drugs 2016; 76(7): 779-87. https://doi.org/10.1007/s40265-016-0568-1

18. Walther S, Stegmayer K. [Diagnosis and treatment of motor phenomena in schizophrenia spectrum disorders]. Ther Umsch 2018; 75(1): 31-6. https://doi.org/10.1024/ 0040-5930/a000963

19. Shireen E. Experimental treatment of antipsychotic-induced movement disorders. J Exp Pharmacol 2016; 8: 1-10. https://doi.org/10.2147/JEP.S63553

20. Kulkarni SK, Naidu PS. Pathophysiology and drug therapy of tardive dyskinesia: current concepts and future perspectives. Drugs Today (Barc) 2003; 39(1): 19-49. https://doi.org/10.1358/dot.2003.39.1.799430

21. Ali Z, Roque A, El-Mallakh RS. A unifying theory for the pathoetiologic mechanism of tardive dyskinesia. Med Hypotheses 2020; 140: 109682. https://doi.org/10.1016/ j.mehy.2020.109682

22. Patel RS, Mansuri Z, Motiwala F, Saeed H, Jannareddy N, Patel H, et al. A systematic review on treatment of tardive dyskinesia with valbenazine and deutetrabenazine. Ther Adv Psychopharmacol 2019; 9: 2045125319847882. https://doi.org/10.1177/2045125319847882

23. Cornett EM, Novitch M, Kaye AD, Kata V, Kaye AM. Medication-induced tardive dyskinesia: a review and update. Ochsner J 2017; 17(2): 162-74.

24. Solmi M, Pigato G, Kane JM, Correll CU. Treatment of tardive dyskinesia with VMAT-2 inhibitors: a systematic review and meta-analysis of randomized controlled trials. Drug Des Devel Ther 2018; 12: 1215-38. https://doi.org/10.2147/ DDDT.S133205

25. Caroff SN. Overcoming barriers to effective management of tardive dyskinesia. Neuropsychiatr Dis Treat 2019; 15: 785-94. https://doi.org/10.2147/NDT.S196541

26. Scherman D, Weber MJ. Characterization of the vesicular monoamine transporter in cultured rat sympathetic neurons: persistence upon induction of cholinergic phenotypic traits. Dev Biol 1987; 119(1): 68-74. https://doi.org/10.1016/ 0012-1606(87)90207-7

27. Erickson JD, Eiden LE, Schäfer MK-H, Weihe E. Reserpineand tetrabenazine-sensitive transport of ${ }^{3} \mathrm{H}$-histamine by the neuronal isoform of the vesicular monoamine transporter. J Mol Neurosci 1995; 6(4): 277-87. https://doi.org/10.1007/ BF02736786

28. Erickson JD, Schafer MK, Bonner TI, Eiden LE, Weihe E. Distinct pharmacological properties and distribution in neurons and endocrine cells of two isoforms of the human vesicular monoamine transporter. Proc Natl Acad Sci U S A 1996; 93(10): 5166-71. https://doi.org/10.1073/pnas.93.10.5166

29. Kaur N, Kumar P, Jamwal S, Deshmukh R, Gauttam V. Tetrabenazine: spotlight on drug review. Ann Neurosci 2016; 23(3): 176-85. https://doi.org/10.1159/000449184

30. Quinn GP, Shore PA, Brodie BB. Biochemical and pharmacological studies of Ro 1-9569 (tetrabenazine), a non-indole tranquilizing agent with reserpine-like effects. J Pharmacol Exp Ther 1959; 127(2): 103-9.

31. Kazamatsuri H. Treatment of tardive dyskinesia. I. Clinical efficacy of a dopamine-depleting agent, tetrabenazine. Arch Gen Psychiatry 1972; 27(1): 95-9. https://doi.org/10.1001/ archpsyc. 1972.01750250081011

32. Kilbourn MR, Lee LC, Heeg MJ, Jewett DM. Absolute configuration of $(+)$ - $\alpha$-dihydrotetrabenazine, an active metabolite of tetrabenazine. Chirality 1997; 9(1): 59-62.
https://doi.org/10.1002/(SICI)1520-636X(1997)9:1<59::AI D-CHIR11>3.0.CO;2-P

33. Müller T. Valbenazine granted breakthrough drug status for treating tardive dyskinesia. Expert Opin Investig Drugs 2015; 24(6): 737-42. https://doi.org/10.1517/13543784. 2015.1029573

34. Bhidayasiri R, Jitkritsadakul O, Friedman JH, Fahn S. Updating the recommendations for treatment of tardive syndromes: a systematic review of new evidence and practical treatment algorithm. J Neurol Sci 2018; 389: 67-75. https://doi.org/ 10.1016/j.jns.2018.02.010

35. Hauser RA, Factor SA, Marder SR, Knesevich MA, Ramirez PM, Jimenez R, et al. KINECT 3: a phase 3 randomized, double-blind, placebo-controlled trial of valbenazine for tardive dyskinesia. Am J Psychiatry 2017; 174(5): 476-84. https://doi.org/10.1176/appi.ajp. 2017.16091037

36. Josiassen RC, Kane JM, Liang GS, Burke J, O'Brien CF. Long-term safety and tolerability of valbenazine (NBI-98854) in subjects with tardive dyskinesia and a diagnosis of schizophrenia or mood disorder. Psychopharmacol Bull 2017; 47(3): 61-8.

37. Khorassani F, Luther K, Talreja O. Valbenazine and deutetrabenazine: vesicular monoamine transporter 2 inhibitors for tardive dyskinesia. Am J Health Syst Pharm 2020; 77(3): 167-74. https://doi.org/10.1093/ajhp/zxz299

38. Fernandez HH, Factor SA, Hauser RA, Jimenez-Shahed J, Ondo WG, Jarskog LF, et al. Randomized controlled trial of deutetrabenazine for tardive dyskinesia. Neurology 2017; 88(21): 2003-10. https://doi.org/10.1212/WNL. 0000000000003960

39. Anderson KE, Stamler D, Davis MD, Factor SA, Hauser RA, Isojärvi J, et al. Deutetrabenazine for treatment of involuntary movements in patients with tardive dyskinesia (AIM-TD): a double-blind, randomised, placebo-controlled, phase 3 trial. Lancet Psychiatry 2017; 4(8): 595-604. https://doi.org/10.1016/S2215-0366(17)30236-5

40. VVKT - Vaistai [Internet]. Available from: https://vapris.vvkt.lt/vvkt-web/public/medications

41. Pappa S, Tsouli S, Apostolou G, Mavreas V, Konitsiotis S. Effects of amantadine on tardive dyskinesia: a randomized, double-blind, placebo-controlled study. Clin Neuropharmacol 2010; 33(6): 271-5. https://doi.org/ 10.1097/WNF.0b013e3181ffde32

42. Zhang W-F, Tan Y-L, Zhang X-Y, Chan RCK, Wu H-R, Zhou D-F. Extract of ginkgo biloba treatment for tardive dyskinesia in schizophrenia: a randomized, double-blind, placebo-controlled trial. J Clin Psychiatry 2011; 72(5): 615-21. https://doi.org/10.4088/JCP.09m05125yel

43. Zheng W, Xiang Y-Q, Ng C, Ungvari G, Chiu H, Xiang Y-T. Extract of ginkgo biloba for tardive dyskinesia: meta-analysis of randomized controlled trials. Pharmacopsychiatry 2016; 49(03): 107-11. https://doi.org/10.1055/ s-0042-102884

44. Thaker GK, Nguyen JA, Strauss ME, Jacobson R, Kaup BA, Tamminga CA. Clonazepam treatment of tardive dyskinesia: a practical GABAmimetic strategy. Am J Psychiatry 1990; 147(4): 445-51. https://doi.org/10.1176/ajp.147.4.445

45. Hatcher-Martin JM, Armstrong KA, Scorr LM, Factor SA. Propranolol therapy for tardive dyskinesia: a retrospective examination. Parkinsonism Relat Disord 2016; 32: 124-6. https://doi.org/10.1016/j.parkreldis.2016.09.004

46. Libov I, Miodownik C, Bersudsky Y, Dwolatzky T, Lerner V. Efficacy of piracetam in the treatment of tardive 
dyskinesia in schizophrenic patients: a randomized, double-blind, placebo-controlled crossover study. J Clin Psychiatry 2007; 68(7): 1031-7. https://doi.org/10.4088/ JCP.v68n0709

47. Woods SW, Saksa JR, Baker CB, Cohen SJ, Tek C. Effects of levetiracetam on tardive dyskinesia: a randomized, doubleblind, placebo-controlled study. J Clin Psychiatry 2008; 69(4): 546-54. https://doi.org/10.4088/JCP.v69n0405

48. Bhidayasiri R, Fahn S, Weiner WJ, Gronseth GS, Sullivan KL, Zesiewicz TA. Evidence-based guideline: treatment of tardive syndromes: report of the Guideline Development Subcommittee of the American Academy of Neurology. Neurology 2013; 81(5): 463-9. https://doi.org/ 10.1212/WNL.0b013e31829d86b6

49. Morigaki R, Mure H, Kaji R, Nagahiro S, Goto S. Therapeutic perspective on tardive syndrome with special reference to deep brain stimulation. Front Psychiatry 2016; 7: 207. https://doi.org/10.3389/fpsyt.2016.00207

\section{Pabarčiūtè, M. Karnickas}

\section{TREATMENT OF TARDIVE DYSKINESIA CAUSED BY LONG-TERM ANTIPSYCHOTIC USE: CASE REPORTS AND LITERATURE REVIEW}

\section{Summary}

Introduction. Tardive dyskinesia is a movement disorder that begins with exposure to dopamine receptor-blocking agents for at least a few months. These agents include most of antipsychotics, which are widely used to treat mental illness. This disabling condition will remain a clinical part of modern psychiatry, and the large number of publications on tardive dyskinesia that have appeared in the literature in recent years is a huge step forward in this area.
Case descriptions. A 43-year-old woman with paranoid schizophrenia was hospitalized in 2018 due to constant involuntary movements of the whole body, especially expressed for $\sim 2$ years. The patient had been taking antipsychotics for about 20 years, the first dyskinetic movements were observed $\sim 10$ years ago (various jerks) and described in 2014 (champing). Tardive dyskinesia was diagnosed and the patient was treated with tetrabenazine. The patient's condition in the hospital clearly improved, the stereotypical dystonic-hyperkinetic movements of the limbs and torso and other symptoms disappeared.

Another patient, a 55-year-old woman hospitalized for involuntary movements in 2019, had been regularly taking antipsychotics for delusional disorder for $\sim 10$ years. Akathisia and hand dyskinesia appeared $\sim 7$ years ago and gradually progressed to choreoathetoid movements of the face, neck, arms, and torso. Paranoid schizophrenia and tardive dyskinesia were diagnosed during hospitalization and treatment with tetrabenazine was initiated. During treatment, the amplitude of involuntary movements partially decreased and the patient became more functional.

Literature review. One of the difficulties in treating tardive dyskinesia in psychiatry is the need to continue the antipsychotics that caused the condition. In this case, the best choice would be second-generation atypical antipsychotics. The first-line treatment for tardive dyskinesia is VMAT2 inhibitors - deutetrabenazine, valbenazine; if they are not available - tetrabenazine.

Conclusions. In order to provide reliable evidence-based recommendations for the treatment of tardive dyskinesia and to better understand its pathophysiology, genetic predisposition, and therapeutic agents, more studies with larger samples and more uniform conditions are needed.

Keywords: tardive dyskinesia, treatment of tardive dyskinesia.

Gauta:

20201215

Priimta spaudai: 20210103 